\title{
A Comparative Study of FIIs \& DIIs Investment in Indian Capital Market
}

\author{
Shwetabh Mittal ${ }^{*}$ \\ Faculty of Commerce \& Business Administration, M.M.H. College, Ghaziabad 201001 (U.P.) India \\ Email Id: shwetabhm11@gmail.com
}

\begin{abstract}
The primarily aim of this study is to know the impact of FIIs $\mathcal{E}$ DIIs Investment in Large Cap Companies of India and NIFTY, alongwith NSE Benchmark Index. The study has been based on large cap selected companies of NSE and carried out by selecting mainly three factors: FIIs $\mathcal{E}$ DIIs Investment in Large Cap Companies of India, NIFTY and the NSE Benchmark Index. This study covered a period of 5 years starting from 2014-15 to 2018-19. The statistical techniques applied in this study are basically calculation of, Mean, Standard Deviation, and Karl Pearson's correlation. Linear regression analysis has been used to get the result. Pearson Correlation coefficient, is $0.279 ;-0.088$ and 0.108 between FIIs $\mathcal{E}$ DIIs, FIIs $\mathcal{E}$ NIFTY and DIIs \& NIFTY which shows the low degree of positive correlation between FIIs \& DIIs and DIIs \& NIFTY, whereas it is a low degree of negative correlation between FIIs and NIFTY as the coefficient is between 0 and 1.
\end{abstract}

Key Words: DIIs, FIIs, Large Cap Companies, NIFTY.

\section{PAPER/ARTICLE INFO} RECEIVED ON: 22/08/2019 ACCEPTED ON: 15/10/2019

Reference to this paper should be made as follows:

Shwetabh Mittal (2019), “A Comparative Study of FIIs \& DIIs Investment in Indian Capital Market", Int. J. of Trade and Commerce-IIARTC, Vol. 8, No. 2, pp. 263-274 
A Comparative Study of FIIs \& DIIs Investment in Indian Capital Market

Shwetabh Mittal

1. INTRODUCTION

1.1 Capital Market

Capital market is a big platform for long-term financial instruments and securities. People can invest for short-term and medium-term also. It is the place where Equity Shares, Preference Shares, Debentures, Bonds, Mutual Funds, and Derivatives are bought and sold. A dynamic and developed Capital Market has a great influence on the economy. It speeds up economic growth and development.

\subsection{Indian Capital Market}

Indian capital market till independence exhibited backwardness. As the time passage, it has arrived at a place of maturity because Indian Government took various steps to regulate the capital market. These are: Firstly, to protect the interests of investors, elaborate legislative measures have been taken by the Government from time to time. In this phase Government has brought in existence some important Acts like the Companies Act, 1956, the Capital Issues (Control) Act, 1947, the Securities Contracts (Regulation) Act, 1956. Secondly, Indian Government understood the requirement of finance, therefore, many new financial institutions has been established as well as some are nationalised in the interest of countrymen. Some of them are Industrial Finance Corporation of India (1948), Industrial Credit and Investment Corporation of India (1955), Industrial Development Bank of India (1964), Industrial Reconstruction Bank of India (1971), Unit Trust of India (1964) and Life Insurance Corporation of India (1956). Presently, Industrial Credit and Investment Corporation of India and Industrial Development Bank of India has been converted into Commercial Bank. Thirdly, the drastic change has taken place in Indian Capital Market with the establishment of SEBI in 1988. Since then the investment doors of Indian Capital Market has been opened to Foreign Institutional Investors.

\subsection{Domestic Institutional Investors}

Domestic institutional investors are those institutional investors which undertake investment in securities and other financial assets of the country. Institutional investment is defined to be the investment done by institutions or organizations such as banks, insurance companies, mutual fund houses, etc in the financial or real assets of a country. Simply stated, domestic institutional investors use pooled funds to trade in securities and assets of their country. These investment decisions are influenced by various domestic economic as well as political trends. In addition to the foreign institutional investors, the domestic institutional investors also affect the net investment flows into the economy.

\subsection{Foreign Institutional Investors}

A foreign institutional investor (FII) is an investor or investment fund registered in a country outside of the one in which it is investing. Institutional investors most notably include hedge funds, insurance companies, pension funds, and mutual funds. The term is used most commonly in India and refers to outside companies investing in the financial markets of India. A foreign 
institutional investor (FII) is any type of large investor who does business in a country other than the one in which the investment instrument is being purchased. In addition to the types of investors above, others include banks, large corporate buyers or representatives of large institutions. All FIIs take a position in a foreign financial market on behalf of the home country in which they are registered.

For example, a mutual fund in the United States sees an investment opportunity in an Indianbased company; it can purchase the equity on the Indian public exchange and take a long position in a high-growth stock. This also benefits domestic private investors who may not been able to register with the Securities and Exchange Board of India. Instead, they can invest in the mutual fund and take part in the high growth potential.

\section{LiterATURE REVIEW}

1. Juman, B.K.M. and Irshad, M.K. (2015) concluded that Capital markets were not well organized and developed during the British rule. But in the present scenario, we find that Capital markets are well developed after the introduction of SEBI. Through provision of long term loans, the capital market brings about effective functioning of various sectors of the economy. A sound and efficient capital market is one of the most instrumental factors in the economic development of a nation.

2. Malhotra (2015) has examined growth, challenges and future of National Stock Exchange in her paper. She stated that Indian market has gained from foreign inflows through the investment of Foreign Institutional Investors (FIIs). Following the implementation of reforms in the securities industry in the past few years, Indian stock markets have stood out in the world ranking.

3. Patnaik \& Shah (2013) explained the working presented at IMF shows that, the organization where domestic investment is higher tends to deliver superior growth and return on investment, in fact, as being in the same nation, DIIs possess latest technology regarding the financial investments and also have the firm knowledge of nation's working methods. The study also suggests that, the organization with high concentration of FIIs tends to increase its capital and usually the organization with high volume of DIIs use to financially sound and dependable.

4. Ramesh, N.G.S (2019) has put a picture of Indian Capital Market in his speech in the AGM of SHCIL, 2019. He told that growth in equity markets has kept pace with India's GDP growth and has provided a much needed impetus to the economy. As per the World Bank estimates, the Indian economy has grown at 6.8 per cent in 2016-17 and is expected to reach 7.7 per cent by 2019-2020. India with its favorable demographics is a leading growth engine for the world economy. He also emphasizes the Goods and Services Tax Acts as is a step in the direction of improving the ease of doing business. This is likely to change the business environment in the country. As the biggest tax reform since independence, implementing the landmark Goods 
and Services Tax (GST) will promote the competitiveness and productivity of Indian companies which would again contribute to a growing market.

5. Rastogi, S.K. and Kumar, P. (2018), studied that capital market in any country plays a pivotal role in the growth of economy and meeting country's socio economic goals. They were an important constituent of the financial system, given their role in the financial intermediation process and capital formation of the country. The importance of the capital market could not be underemphasized for developing economy like India which needs significant amount of capital for the development of strong infrastructure. In this paper authors have discussed the conceptual framework of the capital market; trends in the capital market in India; and various issues and challenges of the capital market in India.

6. Rastogi, S.K. and Kumar, P. (2018), explained that Indian Stock Market is a hotspot of investment not only among the retail investors but also among Indian Institutional Investors and Foreign Institutional Investors since 1991, when PM Narsimha Rao government opened the door of Indian Economy to the global investors. The investment by Foreign Institutional Investors (FIIs) has become a dynamic force in the development of Indian stock market and a cause of stock market volatility. In the present study an attempt has been done to develop an understanding of the FIIs investment and its impact on stock market volatility. The study is conducted with the help of time series based on monthly closing data of NIFTY, SENSEX and FIIs activity over a period of twenty five years from January, 1994 to November, 2018. In this study, different statistical techniques such as Mean, SD, Coefficient of Variance Karl Pearson's Skewness and Correlation are used to test the impact of investment by FIIs on volatility of Indian stock market. The study reveals that FIIs investment has statistically significant influence on volatility of NIFTY and SENSEX, used as key indicators of Indian stock market.

7. Sam \& Salami, K. (2014), elucidated that there was positive significant effect of capital market development (MKT) and FDI on GDP growth. However, GFI, T-Bills, and INF met their expected signs, but they had insignificant effects on GDP growth. There was also a bidirectional relationship between GDP growth and capital market development. However, the direction of causality is stronger from capital market development to economic growth. This supports the supply-leading hypothesis view of financial development which states that economic growth and development spring from availability of credit facilities from surplus spending units to deficit spending units in an economy.

8. Shenoy, S.S. and Dr. Hebbar, C. K. (2015), made it clear that India being an emerging economy need more innovations and reforms in the capital market. Innovation and reforms not only add value in the existing technology and system but also lead to decrease in the cost of capital and mitigate the risk exposure of the capital market instruments. However, this may entail huge investment in IT infrastructure. Economic growth needs sound financial system which further requires a well-developed capital market. Emerging economies like India need to further sustain the reforms that have been initiated, remove bottlenecks, 
educate investors, provide investor protection, bring in more transparency in operations and refine policies to increase the depth and reach of the capital market and to make it as competitive as the world's best stock markets.

9. Shrikanth \& Kishore (2012), there is positive relationship between FIIs and Indian capital market, because Indian capital market received a push towards growth ever since the foreign institutional investors injected their funds, not only this, FIIs behaves as an market expert, where they control the operation of market as well as, pool up small savings from individual investors to the huge amount of funding process. In fact, FIIs gives the taste of investing in capital market to individual investor too.

10. Singh, V.R. (2014), explained that Capital market is playing its important role in the development of Indian economy. Indian capital market suffered bruises in the last part of the nineties owing to the manipulative trade practices of unscrupulous brokers and other participants. With the kind and the quality of human skills possessed by India's financial Industry, it is quite imperative that there is need to provide sound capital foundation for the stock market. It is to be noted with happiness that Government of India has successfully introduced the derivative trading in the stock exchanges. There are many issues, which require immediate and urgent attention of the planners concerned.

11. Suman and Warne (2012) investigated that FIIs played an important role in Indian stock market. Securities Exchange Board of India (SEBI) gave a lot of stock market reforms after the year 2000. These reforms affected the FIIs to a large extent. They included the stock market reforms which were directly related to FIIs. These reforms were, the increased limit of investment up to $100 \%$ in tourism, highways etc., get permission to invest in debt and government securities up to a certain limit, internet trading, get permission for short selling according to the rule of SEBI, ban on carried forward transactions etc. The authors showed the effect of these stock market reforms on FIIs with the help of increased trend of investment in foreign institutional investment, increased no. of SEBI registered FIIs etc. Finally these reforms have positive effect on FIIs.

12. V. Aditya Srinivas (2016) studied the importance of FII money for Indian stock market. He focused on the global integration of economies and its effects on the Indian economy and stock market. The author covered the statistical analysis of FII (Foreign Institutional investor) flows and its impact on the index from 2008 to 2013, with a focus on Global financial crisis of 2008 and Euro zone crisis of 2011. The impact of the FII flows during the two crises has been analyzed. The researcher has used $\mathrm{t}$-test, correlation, regression analysis to identify the relation between FII and Indian stock market. The coefficient of correlation is 0.41 showed positive correlation and proved the significant relationship between the FII flows and the index. In this paper the author also suggested that investors' protection should be made mandatory. There should be an early education of the finance and stock market so that investors understand it better. 
13. Varughese and Thomas (2015), explained that the FIIs have been playing a key role in the Indian financial markets since their entry into this country in the early 1990s. Their importance has been growing over time as their net investment is on the rise over time. This paper analysed importance of foreign capital, the role of FIIs in Indian Equity and Debt market and compared the investment activities of FIIs and domestic institutional Investments. They concluded that FIIs has certainly posed some threats to the Indian stock market considering its influence on the market.

\section{OBJectives OF THE STUDY}

1. To analyse the Investment Pattern of FIIs \& DIIs in Large Cap Companies of India.

2. To analyse the impact of FIIs \& DIIs in Large Cap Companies of India on NIFTY, the NSE Benchmark Index.

\section{HYPOTHESIS OF THE STUDY}

$\mathbf{H}_{01}$ : There is no significant relationship between FIIs Investment in Large Cap Companies of India and NIFTY, the NSE Benchmark Index.

$\mathbf{H}_{02}$ : There is no significant relationship between DIIs Investment in Large Cap Companies of India and NIFTY, the NSE Benchmark Index.

$\mathbf{H}_{\mathrm{a} 1}$ : There is a significant relationship between FIIs Investment in Large Cap Companies of India and NIFTY, the NSE Benchmark Index.

$\mathbf{H}_{\mathrm{a} 2}$ : There is a significant relationship between DIIs Investment in Large Cap Companies of India and NIFTY, the NSE Benchmark Index.

\section{Research Methodology}

The primarily aim of this study is to know the impact of FIIs \& DIIs Investment in Large Cap Companies of India and NIFTY, the NSE Benchmark Index. This study is based on secondary data.

5.1 Sample Design: The study has been based on large cap selected companies of NSE and carried out by selecting mainly three factors: FIIs \& DIIs Investment in Large Cap Companies of India and NIFTY, the NSE Benchmark Index.

5.2 Data Collection Method: This study is based on secondary data. It is based on published annual reports for the period 2014-15 to 2018-19 of Selected Large Cap Companies, National Stock Exchange and Mumbai Stock Exchange. The data have also been collected from Bulletins of Reserve Bank of India.

5.3 Study Period: This study covered a period of 5 years starting from 2014-15 to 2018-19 taking into consideration the availability of data for the choosing study period.

5.4 Tools and Techniques of Data Analysis: Various statistical formulas are used for data analysis. The statistical techniques applied in this study are basically calculation of, Mean, Standard Deviation, and Karl Pearson's correlation. Linear regression analysis has been used to get the result. 


\section{DATA ANAlysis}

We have taken the share holding pattern of 10 large cap companies operating in BSE and NSE, which belongs to different industries.

Table 1: FIIs Investment in Large Cap Companies

(During 2014-15 to 2018-19)

In percentage of total Issued Share Capital

\begin{tabular}{|c|c|c|c|c|c|c|c|c|c|c|c|}
\hline \multirow[b]{2}{*}{ Year } & \multicolumn{11}{|c|}{ Large Cap Selected Companies } \\
\hline & 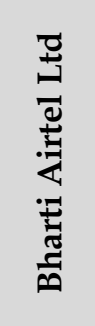 & 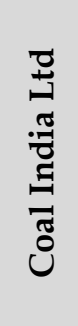 & 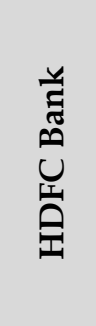 & 䛼 & 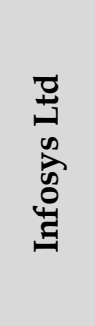 & 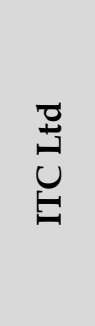 & 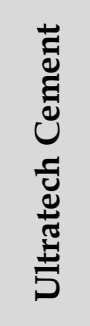 & 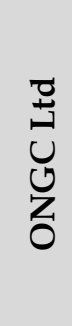 & 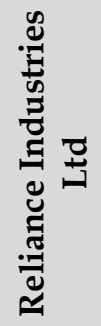 & $\bigcup_{H}^{\infty}$ & 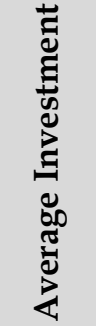 \\
\hline 2015 & 17.93 & 8.99 & 32.57 & 15.01 & 37.96 & 16.74 & 19.32 & 7.18 & 18.81 & 14.94 & 18.95 \\
\hline 2016 & 16.78 & 8.52 & 32.22 & 14.20 & 40.24 & 20.44 & 19.01 & 5.60 & 19.54 & 10.16 & 18.67 \\
\hline 2017 & 15.22 & 6.46 & 34.35 & 13.26 & 38.31 & 20.03 & 21.87 & 6.29 & 21.94 & 16.90 & 19.46 \\
\hline 2018 & 18.45 & 5.50 & 33.06 & 12.56 & 35.24 & 17.96 & 22.27 & 5.47 & 23.82 & 16.90 & 19.12 \\
\hline 2019 & 17.61 & 7.14 & 31.24 & 11.83 & 34.04 & 17.01 & 20.00 & 6.47 & 25.46 & 15.80 & 18.66 \\
\hline Mean & 17.20 & 7.32 & 32.69 & 13.37 & 37.16 & 18.44 & 20.49 & 6.20 & 21.91 & 14.94 & -- \\
\hline $\begin{array}{l}\text { Standard } \\
\text { Deviation }\end{array}$ & 1.26 & 1.44 & 1.14 & 1.27 & 2.49 & 1.71 & 1.49 & 0.70 & 2.81 & 2.80 & -- \\
\hline Minimum & 15.22 & 5.50 & 31.24 & 11.83 & 34.04 & 16.74 & 19.01 & 5.47 & 18.81 & 10.16 & -- \\
\hline Maximum & 18.45 & 8.99 & 34.35 & 15.01 & 40.24 & 20.44 & 22.27 & 7.18 & 25.46 & 16.90 & -- \\
\hline
\end{tabular}

Source: Annual Reports of Selected Companies

Table No. 1 shows that average FIIs shareholding in Infosys Limited and HDFC Bank is approximately one third of the total share issued. Average FIIs shareholding in these companies is 37.16 and 32.69 percentage. The holding of FIIs in other selected companies is followed by RIL 21.91\%, Ultratech Cement Limited 20.49, ITC Limited 18.44\%, Bharti Airtel Limited 17.20\%, TCS Limited 14.94\%, HUL 13.37\%, Coal India Limited 7.14 and ONGC Limited $6.20 \%$.

Table No. 1 also indicates that FIIs investment in RIL and TCS are most fluctuating as Standard Deviation 2.81 and 2.82 respectively is the most, on the other hand it is most constant in ONGC Limited, with Standard Deviation (0.70).

During the study period, FIIs Investment in ONGC Limited in 2017-18 is the least with 5.47\% and maximum (40.24\%) in HDFC Bank Limited in 2015-16. 
A Comparative Study of FIIs \& DIIs Investment in Indian Capital Market Shwetabh Mittal

Table 2: DIIs Investment percentage in Large Cap Companies

(During 2014-15 to 2018-19)

In percentage of total Issued Share Capital

\begin{tabular}{|c|c|c|c|c|c|c|c|c|c|c|c|}
\hline \multirow[b]{2}{*}{ Year } & \multicolumn{11}{|c|}{ Large Cap Selected Companies } \\
\hline & 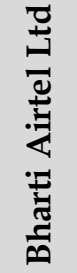 & 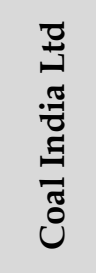 & 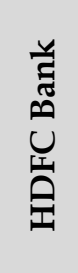 & $\stackrel{\Xi}{\Xi}$ & 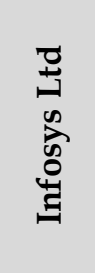 & 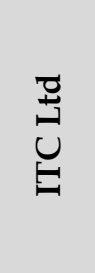 & 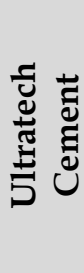 & 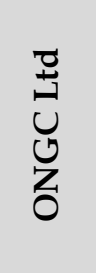 & 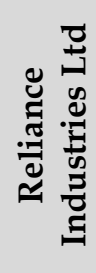 & $\bigcup_{n}^{n}$ & 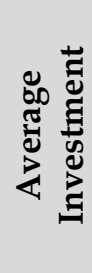 \\
\hline 2015 & 4.8 & 8.11 & 2.93 & 3.5 & 9.8 & 33.08 & 2.96 & 9.5 & 10.11 & 4.8 & 8.96 \\
\hline 2016 & 7.48 & 7.24 & 2.81 & 3.93 & 10.82 & 32.52 & 3.17 & 10.46 & 9.85 & 7.48 & 9.58 \\
\hline 2017 & 7.94 & 9.54 & 2.49 & 3.88 & 11.97 & 31.74 & 2.89 & 10.56 & 8.77 & 7.94 & 9.77 \\
\hline 2018 & 5.77 & 11.29 & 2.31 & 5.21 & 10.81 & 30.7 & 3.17 & 10.81 & 8.21 & 5.77 & 9.41 \\
\hline 2019 & 4.93 & 12.89 & 2.34 & 4.89 & 9.32 & 29.58 & 4.78 & 10.98 & 10.12 & 4.93 & 9.48 \\
\hline Mean & 6.18 & 9.81 & 2.58 & 4.28 & 10.54 & 31.52 & 3.39 & 10.46 & 9.41 & 6.18 & -- \\
\hline Std. & & & & & & & & & & & -- \\
\hline Deviation & 1.45 & 2.30 & 0.28 & 0.73 & 1.03 & 1.41 & 0.78 & 0.58 & 0.87 & 1.45 & \\
\hline Minimum & 4.80 & 7.24 & 2.31 & 3.50 & 9.32 & 29.58 & 2.89 & 9.50 & 8.21 & 4.80 & -- \\
\hline Maximum & 7.94 & 12.89 & 2.93 & 5.21 & 11.97 & 33.08 & 4.78 & 10.98 & 10.12 & 7.94 & -- \\
\hline
\end{tabular}

Source: Annual Reports of Selected Companies

Table No. 2 shows that average DIIs shareholding in ITC Limited is approximately one third of the total share issued. Average DIIs shareholding in ITC Limited is 31.52 percentage. The holding of DIIs in other selected companies is followed by Infosys Limited $10.54 \%$, ONGC Limited 10.46\%, Coal India Limited 9.81, RIL 9.41\%, ITC Limited 6.18\%, Bharti Airtel Limited 6.18\%, HUL 4.28\%, Ultratech Cement Limited 3.39 and HDFC Bank 2.58\%. Table No. 2 also indicates that DIIs investment in Coal India Limited is most fluctuating as Standard Deviation (2.30) is the most, on the other hand it is most constant in HDFC Bank Limited, with Standard Deviation (0.28). During the study period, DIIs Investment in HDFC Bank Limited in 2017-18 is the least with $2.31 \%$ and maximum (33.08\%) in ITC Limited in 2014-15. 
Table 3: Closing Price of Large Cap Companies

(As on last Trading day of Financial Year During 2014-15 to 2018-19)

\begin{tabular}{|c|c|c|c|c|c|c|c|c|c|c|c|}
\hline \multirow[b]{2}{*}{ Year } & \multicolumn{11}{|c|}{ Large Cap Selected Companies } \\
\hline & 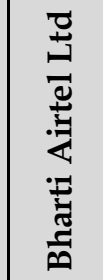 & 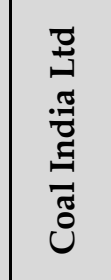 & 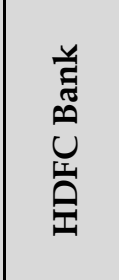 & 主 & 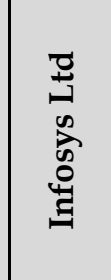 & 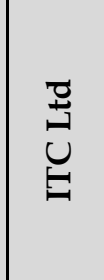 & 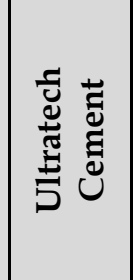 & 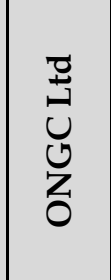 & 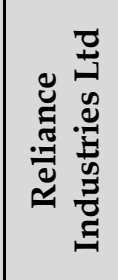 & $\bigcup_{0}^{\infty}$ & 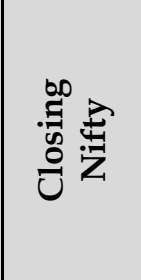 \\
\hline 2015 & 357.55 & 359.3 & 511.35 & 873.55 & 554.6 & 217.2 & 2877.9 & 204.25 & 413 & 1305.15 & 8491.00 \\
\hline 2016 & 325.5 & 295.15 & 535.6 & 861.65 & 609.15 & 218.8 & 3228.75 & 142.75 & 522.6 & 1260.15 & 7738.40 \\
\hline 2017 & 322.5 & 292.65 & 721.3 & 919.2 & 511.15 & 280.3 & 3984.75 & 185 & 660.45 & 1215.9 & 9173.75 \\
\hline 2018 & 366.1 & 283.3 & 943.05 & 1333.35 & 565.9 & 255.5 & 3978.5 & 177.8 & 882.7 & 1424.6 & 10113.70 \\
\hline 2019 & 305.85 & 237.2 & 1159.45 & 1706.8 & 743.85 & 297.25 & 3998.35 & 159.75 & 1360 & 2000.3 & 11623.90 \\
\hline Mean & 335.50 & 293.52 & 774.15 & 1138.91 & 596.93 & 253.81 & 3613.65 & 173.91 & 767.75 & 1441.22 & -- \\
\hline Std. Deviation & 25.35 & 43.61 & 276.47 & 372.78 & 89.23 & 35.91 & 526.38 & 23.61 & 374.64 & 322.07 & -- \\
\hline Minimum & 30585 & 237.20 & 511.35 & 861.65 & 511.15 & 217.20 & 2877.90 & 142.75 & 413.00 & 1215.90 & -- \\
\hline Maximum & 366.10 & 359.30 & 1159.45 & 1706.80 & 743.85 & 297 & 399 & 204.2 & 136 & 2000.30 & -- \\
\hline
\end{tabular}

Source: www.nseindia,com $\mathcal{E}$ www.bseindia.com

Table No. 3 shows that Closing Price of selected large companies, on the basis of maximum closing price the top three selected companies are Ultratech Cement Limited (Rs. 3613.65), TCS Limited (Rs. 1441.22) and HUL (Rs. 1138.91). During the study period Ultratech Cement Limited is the most fluctuating company, on the other hand ONGC Limited is the most constant company.

Table No. 4: Average Investment Percentage by FIIs \& DIIs in Selected Companies and Closing Nifty Index

\begin{tabular}{|c|c|c|c|}
\hline \multirow{2}{*}{ YEAR } & \multicolumn{2}{|c|}{ INVESTMENT } & \multirow{2}{*}{ NIFTY } \\
\cline { 2 - 3 } & FIIs & DIIs & 8491.00 \\
$2014-15$ & 18.95 & 8.96 & 7738.40 \\
$2015-16$ & 18.67 & 9.58 & 9173.75 \\
$2016-17$ & 19.46 & 9.77 & 10113.70 \\
$2017-18$ & 19.12 & 9.41 & 11623.90 \\
$2018-19$ & 18.66 & 9.48 & \\
\hline
\end{tabular}

Table No. 4 shows the average investment of FIIs and DIIs in percentage of total shares issued in selected Large Cap Companies during the study period and Closing value of NIFTY, the benchmark Index of NSE. 
Table No. 5: Karl Pearsons' Correlation

\begin{tabular}{|l|c|c|c|}
\hline & FIIs & DIIs & NIFTY \\
\hline FIIs & 1 & & \\
DIIs & .279 & 1 & 1 \\
NIFTY & -.088 & .108 & 1 \\
\hline
\end{tabular}

Pearson correlation coefficient, is $0.279 ;-0.088$ and 0.108 between FIIs \& DIIs, FIIs \& NIFTY and DIIs \& NIFTY which shows the low degree of positive correlation between FIIs \& DIIs and DIIs \& NIFTY, whereas it is a low degree of negative correlation between FIIs and NIFTY as the coefficient is between 0 and 1 .

The correlation result shows that the Null Hypothesis $\left(\mathrm{H}_{\mathrm{a} 1}\right)$ 'There is a significant relationship between FIIs Investment in Large Cap Companies of India and NIFTY, the NSE Benchmark Index.' is rejected and the Null Hypothesis $\left(\mathrm{H}_{01}\right)$ 'There is no significant relationship between FIIs Investment in Large Cap Companies of India and NIFTY, the NSE Benchmark Index.' is accepted. The correlation result also shows that the Alternative Hypothesis $\left(\mathrm{H}_{\mathrm{a} 2}\right)$ 'There is a significant relationship between DIIs Investment in Large Cap Companies of India and NIFTY, the NSE Benchmark Index.' is accepted and the Null Hypothesis $\left(\mathrm{H}_{01}\right)$ 'There is no significant relationship between DIIs Investment in Large Cap Companies of India and NIFTY, the NSE Benchmark Index.' is rejected.

Table No. 6: Model Summary

\begin{tabular}{|c|c|c|c|c|c|c|c|c|c|}
\hline & & & & \multicolumn{5}{|c|}{ Change Statistics } \\
Model & $\mathbf{R}$ & $\begin{array}{c}\text { R } \\
\text { Square }\end{array}$ & $\begin{array}{c}\text { Adjusted } \\
\text { R Square }\end{array}$ & $\begin{array}{c}\text { of the } \\
\text { Estimate }\end{array}$ & $\begin{array}{l}\text { R Square } \\
\text { Change }\end{array}$ & $\begin{array}{c}\text { F } \\
\text { Change }\end{array}$ & df1 & df2 & $\begin{array}{c}\text { Sig. F } \\
\text { Change }\end{array}$ \\
\hline 1 & $.164^{\mathrm{a}}$ & .027 & -.946 & 2103.07412 & .027 & .028 & 2 & 2 & .973 \\
\hline
\end{tabular}

a. Predictors: (Constant), DIIs, FIIs.

- The correlation co-efficient among the variables is 0.164 which indicates the low degree of positive correlation.

- The co-efficient of determination, $\mathrm{R}^{2}$ is 0.027 . This shows that the variation of the dependent variable (NIFTY) is explained nearly $2.7 \%$ by the explanatory variable (FIIs \& DIIs Investments in Large Cap Selected Companies).

- Adjusted $\mathrm{R}^{2}$ measure the proportion of the variance in the dependent variable that was explained by the variation in the independent variable. "Adjusted $\mathrm{R}^{2}$ shows $94.6 \%$ of variance was explained.

Hence, we reject the null hypothesis at $5 \%$ level of significance. So the estimated results of the model demonstrate that there is significant relationship between NIFTY and FIIs \& DIIs Investment in Large Cap Selected Companies of India.

Table No.7: Coefficients ${ }^{a}$

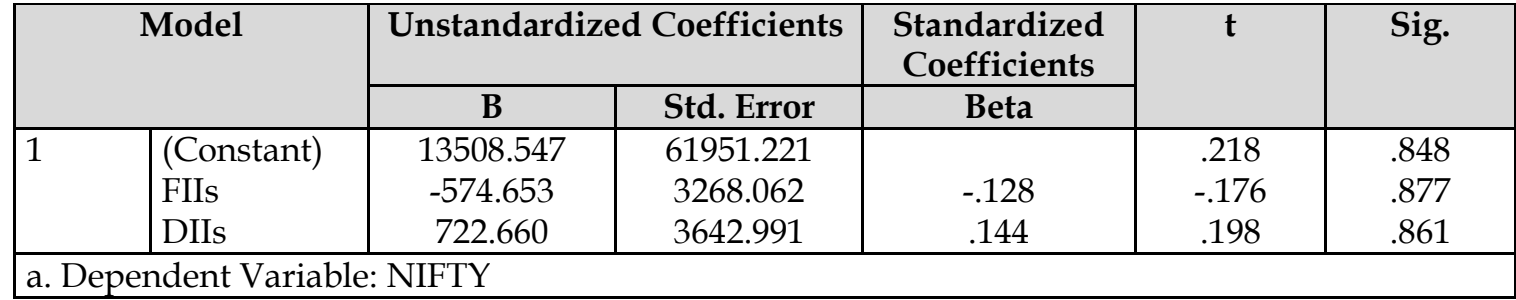

NIFTY= 13508.547 - 574.653 FIIs + 722.660 DIIs. 
- Regression result shows the negative value of $\boldsymbol{\beta 1}$ (-574.653) \& positive value $\boldsymbol{\beta 2}$ (722.660). It indicates that the unit change in the dependent variable due to the change in the value of predictor.

\section{CONCLUSIONS}

Though, share of FIIs and DIIs both determines the health of any economy's capital market, but, still the investment procedure and investment ratio differs for both FIIs and DIIs depending upon the nature of industry and level of investment. In fact, there own pros and cons for both FIIs and DIIs and we cannot eliminate any one investment source completely from the capital market. The FIIS and DIIs Investment in selected large cap companies do not affect the NIFTY movement during the study period. As the study is limited to a period of 5 years and also limited to 10 selected large cap companies only.

\section{REFERENCES}

Articles and Research Papers:

[1]. Juman, B.K.M. and Irshad, M.K., (2015). 'An Overview of India Capital Markets', Bonfring International Journal of Industrial Engineering and Management Science, Vol. 5, No. 2, June, pp. 17-23

[2]. M. Srikanth, and B. Kishore, (2012). 'Net FII Flows into India: A Cause and Effect Study, ASCI Journal of Management, volume 41, issue 2, p. 107 - 120.

[3]. Malhotra, G., (2015). 'Indian Capital Market: Growth, Challenges and Future', XVI Annual Conference Proceedings January.

[4]. Patnaik and Shah, (2013). 'The Investment Technology of Foreign and Domestic Institutional Investors an Emerging Market', Journal of International Money and Finance, 39(C):65-88.

[5]. Ramesh, N.G.S., (2019). Managing Director \& CEO, Stock Holding Corporation of India Ltd., 'Indian Capital Market 2020' Annual Report of SHCIL.

[6]. Rastogi, Dr. S. K. and Kumar, P., (2018). 'Role of Capital Market in India: A Theoretical View', Online International Interdisciplinary Research Journal, \{Bi-Monthly\}, ISSN 22499598, Volume-08, May, Special Issue.

[7]. Rastogi, S.K. and Kumar, P., (2018). Impact of FIIs Investment on Indian Stock Market: An Analysis, International Journal of Trade \& Commerce - IIARTC, Vol. 7, No. II, pp. 367-375,

[8]. Sam \& Salami, K., (2014). 'Effect of Capital Market Development on Economic Growth in Ghana', European Scientific Journal, Edition: March, Vol.10, No.7 ISSN: 1857 - 7881 (Print) e - ISSN 1857- 7431.

[9]. Shenoy, S. S. and Dr. Hebbar, C. K. (2015), A Comparative Study of Stock Market Reforms in India and Select Countries Abroad, Proceedings of International Conference on Management Finance Economics, July 11-12, ISBN:9788193137307

[10]. Singh, V.R., (2014). 'Capital Market and its Role in Indian Financial System', International Journal of Advanced Research in Management and Social Sciences, Vol. 3 | No. 3 | March, pp. 130-140.

[11]. Suman and Warne, (2012). 'Foreign Institutional Investors and Indian Stock Market Reforms', International Journal of Marketing and Technology, Volume 2, Issue 6, ISSN: 2249-1058 
[12]. V. Aditya Srinivas, (2016). 'Indian Capital Market - Impact of FII on Indian Stock Market', Indian Journal of Science and Technology, Vol. 9, Issue 15, ISSN (Print) : 0974-6846 ISSN (Online) : 0974-5645.

[13]. Varughese and Thomas, 'Role of Foreign Institutional Investors on Indian Capital Market', GE-International Journal of Management Research, Vol. 3, Issue 4, Impact Factor 4.316 ISSN: (2321-1709)

\section{Books:}

[1]. Avadhani, V.A. (2011), 'Capital Market Management', Himalaya Publishing House, New Delhi, $4^{\text {th }}$ Ed.

[2]. Bhalla V. K., (2002). 'Portfolio Analysis \& Management', New Delhi, Sultan Chand \& Sons Publication, 9th Edition.

[3]. Kothari and Garg, (2016), 'Research Methodology: Method and Techniques', New Age International Publishers, New Delhi, 3rd Ed.

[4]. Pandian P., (2005). 'Securities Analysis and Portfolio Management', New Delhi, Vikash Publishing House Pvt. Ltd., Year.

[5]. Pathak B. V., (2006). 'The Indian Financial System', Pearson Education (India) Ltd. 2nd Edition, Year.

[6]. Ranganathan M. \& Madhumahi R., (2014). 'Investment Analysis and Portfolio Management', Pearson Education (India) Ltd., New Delhi.

\section{Websites:}

[1]. http://www.sebi.gov.in

[2]. http://www.rbi.org.in

[3]. www.nseindia.com

[4]. www.bseindia.com

[5]. https://economictimes.indiatimes.com 